\title{
Tüketicilerin Kırmızı Et Tüketimi ve Hayvan Refahı Konusundaki Bilinç Düzeylerinin Araştırılması
}

\author{
Investigation of the Awareness Level of Consumers \\ about Red Meat Consumption and Animal Welfare
}

\section{Ali KAYGISIZ1 ${ }^{1 D}$, \\ Adile TATLIYER TUNAZ1 ${ }^{1 D}$, \\ Oğuz ARSLAN² D \\ ${ }^{1}$ Kahramanmaraş Sütçü İmam Üniversitesi, Ziraat Fakültesi, \\ Zootekni Bölümü, Kahramanmaraş, Türkiye \\ ${ }^{2}$ Tarım ve Orman Bakanlığı il Müdürlüğü, Mersin, Türkiye}

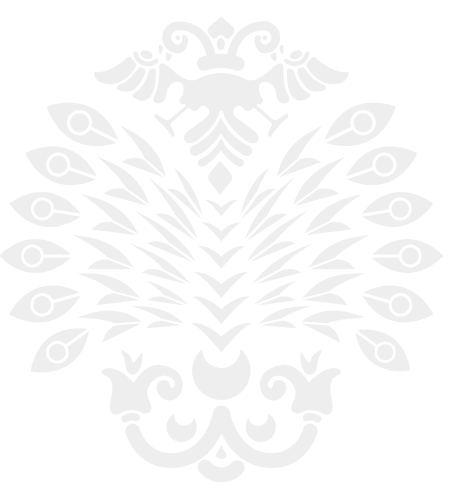

Geliş Tarihi/Received: 15.06.2021

Kabul Tarihi/Accepted: 08.10.2021

Sorumlu Yazar/Corresponding Author: Ali KAYGISIZ

E-mail: alikaygisiz@ksu.edu.tr

Cite this article as: Kaygısız, A., Tatlıyer Tunaz, A., \& Arslan, O. (2022).

Investigation of the awareness level of consumers about red meat consumption and animal welfare. Atatürk University Journal of Agricultural Faculty, 53(1), 24-30.

\section{(c) (1) (5)}

Content of this journal is licensed under a Creative Commons Attribution-NonCommercial 4.0 International License. öz

Bu araştırma, Mersin ilindeki tarım personelinin et tüketimine yönelik tutum ve davranışları ile hayvan refahı konusundaki görüşlerini incelemek amacıyla 2020 yılı Eylül-Kasım aylarında anket yoluyla yüz yüze görüşülerek yürütülmüştür. G*Power 3.0.10 yazılımı ile minumum örnek hacminin hesaplanmasında Priori power analizi T testi yaklaşımından yararlanılmıştır. Buna göre, etki büyüklüğü (d) 0,29; 0,80 güç (1- $\beta$ ); \%95 güven aralığında ve 0,05 hata payı $(\alpha)$ ile minimum örnek hacmi 96 olarak hesaplanmıştır. Çalışma, anketlerin eksik ya da tutarsız olabileceği de göz önünde tutularak araştırmaya katılmayı kabul eden 100 kişi (n) ile yürütülmüştür. Mersin ilindeki tarım personelinin öncelikli olarak "kırmızı eti" $(\% 48,3)$ ve en çok da "sığır" etini $(\% 44,3)$ ve "koyun" $(\% 40,1)$ etini tercih ettiği gözlenmiştir. Kırmızı eti tercih etmeme nedeni öncelikli olarak pahalı olmasından (\%63,7) kaynaklanmaktadır. Katılımcılar arasında kırmızı eti tercih etme nedeninde ise ilk sırayı etin besleyici niteliği $(\% 40,1)$ almaktadır. Tüketicilerin yarısından fazlası kırmızı eti en çok kendi belirledikleri kasaptan satın aldığı (\%51,9), bunun nedeni ise satış yerinin güvenilir (\%71,1) olmasını belirtilmiştir. Kırmızı et en çok kıyma şeklinde satın alınırken (\%40), porsiyonluk et ise en çok kuşbaşı şeklinde satın alınmaktadır $(\% 74,6)$. Kırmızı et tüketim şekli ise en çok mangalda (ızgara) $(\% 31,9)$ formunda tüketilmektedir. Katılımcılar hayvan refahı konusunda en çok "bakım-besleme" parametresinde $(\% 36,2)$ endişe duyarken, çiftlik hayvanlarının yaşamlarında öncelikli $(\% 23,4)$ olarak "olumsuz fiziki şartlar" parametresinin düzeltilmesinin gerekliliğini beyan etmişlerdir. Tüketicinin daha bilinçli hale gelmesi amacıyla kırmızı etin besin madde içeriği ve insan sağlığındaki önemi hakkında çeşitli bilgilendirmeler yapılmalı ayrıca, tüketicilerin hayvan refahı konusunda bilinçlendirilmesi gerekmektedir

Anahtar Kelimeler: Hayvan refahı, tüketici tutum ve davranışları, kırmızı et

\section{ABSTRACT}

This study was conducted by interviewing 100 people face-to-face with the aim of examining the attitudes and behaviors of agricultural personnel towards meat consumption and their views on animal welfare in September-November 2020 in Mersin Province. Ttest approach was conducted in Priori power analysis to calculate the minimum sample size with G*Power 3.0.10 software. Accordingly, the minimum sample size with 0.29 effect size $(d=0.29), 0.80$ power level $(1-\beta=0.80)$, $95 \%$ confidence interval, and 0.05 significance level $(\alpha)$ was calculated as 96 . Considering that the questionnaires may be incomplete or inconsistent, 100 people ( $n$ ) who voluntarily participated in the study were included in the study. It was observed that the agricultural personnel in Mersin province preferred primarily "red meat" (48.3\%) and mostly "beef" meat (44.3\%) and "sheep" (40.1\%). The reason for not choosing red meat is primarily because it is expensive (63.7\%). Among the participants, the first reason for preferring red meat is the nutritious nature of meat (40.1\%). More than half of the consumers stated that they mostly bought red meat from the butcher of their choice (51.9\%), and this was because the place of sale was reliable (71.1\%). Red meat is mostly purchased as minced meat (40\%), while portioned meat is mostly purchased as "cubed" (74.6\%). Red meat consumption method is mostly consumed in the form of barbecue (grilled) (31.9\%). While the participants were most concerned about animal welfare in the "care-feeding" parameter (36.2\%), they declared that the "negative physical conditions" parameter should be corrected as a priority (23.4\%) in life's livestock. In order to make the consumer more conscious, various information should be given about the nutrient content of red meat and its importance in human health. In addition, the consumers need to be made aware of animal welfare.

Keywords: Animal welfare, attitudes and behaviors of consumers, red meat 


\section{Giriş}

Gelecek nesillerin sağlıklı bir şekilde yetişmesi ve insan sağlığının korunması için yeterli ve dengeli beslenme önemlidir. Bu açıdan, günlük alınması gereken hayvansal proteinlerin başında gelen et ve et tüketimi, çağlar boyunca insanoğlunun tükettiği en önemli gıdalardan biridir. Çünkü et, insanoğlunun büyüme-gelişme ve fizyolojik fonksiyonlarının yerine getirilebilmesinde temel ve en önemli hayvansal protein kaynağı olmasının yanında sahip olduğu biyolojik özellikleri nedeniyle de diğer gıda maddeleri ile karşılaştırılamaz bir yerdedir (Saygın \& Demirbaş, 2018).

Et tüketimi, ülkelerin gelişmişlik düzeyinin karşılaştırılması ve yaşam standartlarının belirlenmesinde de önemli bir parametredir (Sarı̈̈zkan ve ark., 2007). Ülkelerin gelişmişlik düzeyi arttıkça karbonhidratlı gıdaların tüketimi azalırken, proteinli gıdaların tüketimi artmaktadır (Saygın \& Demirbaş, 2018). Türkiye'de ise daha çok bitkisel kaynaklı gıdaların tüketimi tercih edilirken, hayvansal kaynaklı gıdaların tüketimi gelişmiş ülkelere göre oldukça geridedir (Saygı \& Bayhan, 2011).

Ekonomik İşbirliği ve Kalkınma Teşkilatı'nın (OECD) 2020 yılı verilerine göre dünyada kişi başına tüketilen toplam kırmızı et miktarı 22 kg/yıl; bu oran gelişmiş ülkelerde 39 kg/yıl iken az gelişmiş ülkelerde 2,85 kg'dır (Anonymous, 2021). Kırmızı "et tüketimi” arzın yüksek olması nedeniyle, Arjantin 'de 51,2 kg, Avustralya'da 50,5 kg, ABD'de 49,8 kg, AB'de 45,4, Kanada'da ve Yeni Zelanda'da 34,3 kg ile dünya ortalamasının üzerindedir. OECD verilerine göre Türkiye'de ise kişi başına toplam kırmızı et tüketimi ise $12,5 \mathrm{~kg}$ ile dünya ortalamasını altındadır (Anonymous, 2020). Aktaş (2020), Türkiye'de son yıllardaki küçükbaş hayvan sayısındaki azalmaya bağlı olarak koyun eti tüketiminde \%22' lik azalma, büyükbaş hayvan eti tüketiminde ise \%107 artış gözlendiğini bildirmiştir.

Türkiye'nin coğrafi özelliklerinin büyükbaş ve küçükbaş hayvan yetiştiriciliğine elverişli olmasına rağmen, kişi başına kırmızı et tüketiminin bu kadar düşük kalması kişi başı gelirin düşük olması ve beyaz etin daha ucuz olmasından kaynaklanmaktadır. Bunun yanında, gelir dağılımındaki eşitsizlik, tüketici tercihleri, yıllık nüfus artışı oranı ve nüfus yapısında meydana gelen değişimler, gelenekler, iklim, tüketicinin eğitimi, etin hijyenik özellikleri, sağlık sorunları, gıda ile ilgili reklamlar, gıda güvenirliği ve kalite, hazır gıda tüketimlerinin artması ve hayvan refahı et tüketiminde etkili sebepler olarak sayılabilir (Taşkın ve ark., 2020).

Yeterli ve dengeli beslenmede olmazsa olmaz ürün olan etin üretimi için yapılan her türlü çalışmada, et tüketimini etkileyen davranışların belirlenmesi gerekmektedir (Yaylak ve ark., 2010). Çünkü, et tüketiminde etkili davranışların belirlenmesi, iç pazarın şekillendirilmesinde, ulusal anlamda gıda politikalarının oluşturulmasında ve yatırımcıların uzun vadeli planlarında, ekonomik açıdan oldukça önem arz etmektedir (Doğan, 2019).

Bu amaçla, literatürde çoğu araştırmacı tarafından Türkiye'de farklı illerde yapılan pek çok çalışma mevcuttur (Karlı \& Bilgiç, 2007; Karakuş ve ark., 2008; Karakaş, 2010; Ergönül, 2011; Lorcu \& Bolat, 2012; Doğan, 2019; Taşkın ve ark., 2020). Kırmızı et tüketimine odaklanan bu araştırmada ise, kırmızı et tüketimindeki alışkanlıklarının belirlenmesi ve et tüketiminin hayvan refahı açısından değerlendirilmesi amaçlanmıştır.

\section{Yöntem}

Araştırmanın materyalini Mersin ilinde 2020 yılında Eylül-Kasım aylarında anket yoluyla yüz yüze görüşülerek elde edilen veriler oluşturmaktadır.

Maksimum örnek hacmine ulaşmak amacıyla G*Power 3.0.10 yazılımı (Faul ve ark., 2007) kullanılmıştır. Priori power analizi T testi yaklaşımıyla yapılmıştır. Buna göre, etki büyüklüğü (d) 0,29; 0,80 güç (1- $\beta)$; \%95 güven aralığında ve 0,05 hata payı $(\alpha)$ ile minimum örnek hacmi 96 olarak hesaplanmıştır. Bu hesaplamaya göre, bu çalışma anketlerin eksik ya da tutarsız olabileceği de göz önünde tutularak araştırmaya katılmayı kabul eden 100 kişi (n) ile yürütülmüştür. Çalışmanın yapılabilmesi için Akdeniz ilçe Tarım ve Orman Müdürlüğünden yasal izin, KSÜ Fen ve Mühendislik Bilimleri Etik Kurul'undan etik kurul izni alınmıştır.

Çalışma anketörlerin kendi öz kaynakları ile yürütülmüş olup, herhangi bir kuruluş tarafından desteklenmemiştir. Çalışmanın örneklem hacmi Mersin-Merkez ilçesinde yürütüldüğünden elde edilen sonuçlar sadece örneklem hacminin alındığı bölgeye özgüdür.

Çalışmada, öncelikle ankete katılan katılımcıların genel karakteristik özellikleri ve tercih edilen et türleri üzerinde durulmuştur. Ardından, kırmızı eti satın alma şekli ve tüketim tercihleri ile et satışlarında hayvan refahının etkisi incelenmiştir.

\section{Bulgular}

\section{Demografik ve Sosyo-Ekonomik Özellikler}

Ankete katılan katılımcıların genel karakteristik özellikleri ile sosyo ekonomik özellikleri Tablo 1'de verilmiştir. Tablo 1'e göre değerlendirmeye alınan katılımcıların \%70'i erkektir. Katılımcıların \%4'ü 17-26 yaş, \%26'sı 27-36 yaş, \%50'si 37-46 yaş, \%17'si 47-56 yaş aralığında ve \%3'ü ise 57 yaşın üzerindedir. Katılımcıların \%74'ü üniversite, \%17'si ön lisans, \%8'i lise ve \%1'1 de ilkokul mezunudur. Hane halkı sayısına bakıldığında, katılımcıların \%37'sinde 4 kişi, \%34'ünde 3 kişi, \%28'sinde 2 ve 5 kişi ve \%1'inde 6 kişiden fazla kişi yaşamaktadır. Aylık ortalama hane geliri 5500 TL'den fazla olanlar katılımcıların \%72'sini, 4500-5500 TL arasında olanlar \%17'sini, 3500-4500 TL arasında olanlar \%8'ini, 2500-3500 TL arasında olanlar \%1'ni ve 1500-2500 TL arasında olanlar \%2'sini oluşturmaktadır.

\section{Kırmızı Et Tüketimine Yönelik Tutum ve Davranış Şekilleri}

Araştırmada, kırmızı et tüketimine yönelik tutum ve davranışlar, cinsiyet, yaş, öğrenim durumu, hanedeki kişi sayısı ve aylık ortalama hane geliri grupları arasındaki farklılıklar dikkate alınmadan incelenerek sonuçlar Tablo 2'de verilmiştir. Tablo 2'ye göre, katılımcıların öncelikli olarak tercih ettikleri et türü \%48,3 ile kırmızı et olup, bunu \%21 ile beyaz et, \%16 ile balık ve \%1 'ile av etleri olmuştur. Etin her türlüsü tercih edenlerin oranı ise \%13,7'dir.

Katılımcılar en çok sığır etini (\%44,3) tercih ederken, bunu sırasıyla koyun eti $(\% 40,6)$ ve keçi eti $(\% 13,9)$ izlemektedir. Kırmızı et tüketim şekli daha çok mangalda $(\% 31,9)$, fırında $(\% 26,6)$ ve haşlama $(\% 18,8)$ şeklindedir. Katılımcıların \%47'si sucuk, sosis ve salam gibi işlenmiş kırmızı et ürünlerini sürekli tükettiğini bildirirken, \%41'i ara sıra tükettiğini, \%12'si ise hiç tüketmediğini bildirmiştir. Kırmızı eti tüketmeyen katılımcılara kırmızı eti tercih etmeme nedenleri sorulduğunda ilk sırayı \%63,7'lik oranla kırmızı etin pahalı olmasından ve ardından \%25,8'i ise kolestrol sebebiyle 
sağlık endişesinden olduğu görülürken, \%9,7'si ise beslenme alışkanlığından dolayı olduğu görülmüştür. Araştırmada, katılımcıların öncelikli olarak kırmızı eti tercih etme nedenini kırmızı etin besleyici olmasından $(\% 40,1)$, lezzetli olmasından $(\% 36,3)$ ve alışkanlık olmasından $(\% 13,6)$ kaynaklandığı saptanmıştır.

Katılımcıların aylık ortalama et tüketimi çoğunlukla 3-4 kg arasında olup (\%45), 3-4 kg'ın altında olanların oranı \%33'dür. Katılımcıların \%53'ü et tüketim durumunun bir önceki yıla göre değişmediğini belirtirken, \%39'u azaldığını belirtmiştir.

\section{Kırmızı Et Satın Alımına Yönelik Tutum ve Davranış Şekilleri}

Katılımcıların eti satın aldığı yer, satın alınan yerin tercih edilme sebebi, satın alırken öncelikli olarak hangi hususlara dikkat ettiği, kırmızı et satın alma şekli ve porsiyonluk eti alma şekli ile ilgili bilgiler Tablo 3'te gösterilmiştir.

Katılımcılar ilk sırada kendilerinin tercih ettikleri belirli bir kasaptan eti satın alırken $(\% 51,9)$, ikinci sırada marketten $(\% 31,8)$ eti satın aldıklarını belirtmişlerdir. Et ve Balık kurumundan et satın alanların oranı ise \%3,9'dur. Katılımcılara etin satın alındığı yerin tercih edilmesinin nedenleri sorulduğunda satış yerinin güvenilir olması (\%71) ilk neden olarak belirlenmiştir. Satış yerinin sağlıklı hayvanlardan elde edilen eti satıyor olması da ikinci sırada gelmektedir $(\% 22,6)$. Bununla birlikte kırmızı eti satın alırken öncelikle etin taze olması katılımcıların dikkat ettiği ilk durumdur (\%65,3). Katılımcılar etin terbiyesinin yapılması durumuna ise \%3,1 oranla son sırada önem vermiştir. Et en çok \%40 oranla kıyma şeklinde katılımcılar tarafından satın alınırken \%2,4 oranla karkas şeklinde satın alınmıştır. Porsiyonluk etin satın alınma şekli \%74,6 oranla kuşbaşı şeklinde iken, \%5,1 oranla biftek şeklinde satın alınma şekli son sıralarda yer almaktadır.

\section{Hayvan Refahına ilişkin Tutum ve Davranışlar}

Tüketicilerin hayvan refahına yönelik tutum ve davranışları Tablo 4'de özetlenmiştir.

Katılımcılara en fazla refah problemi yaşayan hayvan grubuna yönelik soruya verdikleri cevap \%39,4 oranla ilk sırada besi sığırı olurken, süt inekleri \%27,6 ile ikinci sırada yer almıştır. Koyun ise $\% 14,2$ oranla son sırada yer almıştır. Bakım ve besleme \%36,2 oranla, çiftlik hayvanlarının refahı açısından en çok endişelenilen durum olarak ortaya çıkmıştır. Bunu \%14,9 oranla kesim, \%13,8 oranla barınma ve \%9 oranla ötenazi izlemiştir.

Çiftlik hayvanlarının maruz kaldığı refah problemi ile ilgili tutum ve davranışlarda, katılımcılar \%21,1 oranla hayvanlara yeterince bakım ve beslemenin yapılmadığını belirtmişlerdir. Ahır ve ağılların yeterince havalandırılmaması \%20,1 oranında, hayvanların hareket ve dolaşım alanlarının yetersiz olması \%17 oranında yine ahır ve ağılların basık ve dar olması \%13,1 oranında birer refah problemi olarak saptanmıştır. Çalışma kapsamında çiftlik hayvanlarının yaşamlarında öncelikli olarak düzeltilmesi gereken durumlar üzerinde de durulmuştur. Bu bakımdan, katılımcılar öncelikli olarak olumsuz fiziki şartların $(\% 23,4)$ giderilmesi, yetersiz havalandırma ve dar alanın düzeltilmesi (\%22,7), hastalıkların tedavi edilmesi $(\% 13,5)$ hususunda özen gösterilmesi gerektiğini bildirmişlerdir. Düzeltilmesi gereken durumlar arasında en düşük oranları yaralanma $(\% 2,8)$, ısınma sorunları $(\% 4,3)$, acı $(\% 4,9)$ ve susuzluk $(\% 5,3)$ şeklinde belirtmiştir. Katılımcılar, kesim yerinin temizliği ve hijyen koşullarına dikkat edilmesinin (\%41,1) ve kesim esnasında hayvanın strese sokulmamasının $(\% 25,1)$ çiftlik hayvanlarının kesimi esnasında dikkat edilmesi gereken durumlar olarak belirtmişlerdir. Buna ilaveten, katılımcılar hayvan refahı açısından kesim yapacak kişinin tecrübeli olması $(\% 23,1)$ ve işlemin ağrısız olmasının da $(\% 10,7)$ dikkat edilmesi gereken hususlar olduğunu bildirmişlerdir.

Katılımcıların kırmızı et ürünleri satın alırken "Ürün etiketinde refah bilgisine ait bilginin olmasını ister misiniz?" sorusuna verdikleri yanıtlarda, katılımcıların \%77'si “Evet isterim” yanıtını verirken, \%4'ü "Fark etmez" yanıtını vermişlerdir. "Hayvan refahına uygun bir şekilde yetiştirilmiş hayvanlardan elde edilen ürünler için fazladan ücret ödemek ister misiniz?" sorusuna katılımcıların \%52'si "Evet” olarak cevaplarken, \%48'i "Hayır” cevabını vermişlerdir.

Araştırmada üzerinde durulan et tüketimine yönelik tutum ve davranışlar, et satışına yönelik tutum ve davranışlar, hayvan refahına ilişkin tutum ve davranışlar konularında cinsiyet, yaş, öğrenim durumu, hanedeki kişi sayısı ve aylık ortalama hane geliri dikkate alınmadan genel olarak incelenmiştir.

Araştırmada, tüketicilerin yaklaşık \%50'si kırmızı eti tüketirken, \%25'lik kısmı beyaz eti tercih etmektedir. Bu çalışmada elde edilen sonuçlar Aygün ve ark. (2004)'ın Van, Karakuş ve ark. (2008)'ın Gaziantep'te yürüttükleri çalışma ile benzer, Atay ve ark. (2004)'nin Aydın'da yürütülen çalışmada elde edilen sonuçlardan farkııdır. Atay ve ark. (2004), Aydın ilinde tüketicilerin öncelikli olarak beyaz et tercih ettiğini bildirmişlerdir. Bu sonuçlar, tüketici tercihlerinde bölgenin coğrafi konumunun ön planı çıktığını göstermektedir. Dolayısıyla, batı illerinde beslenme alışkanlıkları ile birlikte yemek kültürü de Doğu ve Güneydoğu illerine göre farklılık gösterebilmektedir.

Katılımcıların kırmızı eti satın alma yeri olarak tüketicilerin büyük oranda geleneksel kasap dükkanlarını tercih ettikleri belirlenmiştir. Bu sonuçlar, Adana ilinde yapılan araştırma (Soro \& Gültekin, 2020) sonuçları ile uyumludur

Kırmızı etin elde edildiği hayvan türü bakımından, Mersin ilinde en fazla sığır eti tercih edilmiştir. Bu sonuçlar, Yaylak ve ark. (2010) ile Taşkın ve ark. (2020)'nin elde ettikleri sonuçlar ile uyumludur. Çalışmada Mersin ilinde kırmızı etin elde edildiği hayvan türünde koyun ikinci sırada yer almaktadır. Aygün ve ark. (2004) ile Atay ve ark. (2004)' nın yaptıkları çalışmalarda ise kırmızı etin elde edildiği öncelikli hayvan türü koyundur.

Araştırmanın sonuçlarına göre, kırmızı etin tercih edilme nedenlerinde "etin besleyici ve lezzetli olması" katılımcı görüşlerinin yoğunlaştığı öncelikli kriterlerdir. Bu sonuçlar, Aygün ve ark. (2004), Karakuş ve ark. (2008) ve Taşkın ve ark. (2020)'nın yürüttükleri çalışmalarla örtüşmektedir. Katılımcıların kırmızı etin, yeterli ve dengeli beslenmede insan sağlığında önemli bir role sahip olduğunun bilincinde olmasıyla ilişkilendirilerek, araştırmaya katılanların rejim programlarına özen gösterdikleri söylenebilir (Orak ve ark., 2006). Bununla birlikte, kırmızı etin besleyici özelliğine ilaveten lezzetli olmasından dolayı tercih edilmesinde katılımcıların kendi damak tadına da önem verdikleri söylenebilir.

Eğitim düzeyi ve gelir düzeyi ile ilişkilendirilerek kırmızı et tüketimine yönelik farklı illerde yapılan çalışmalardan elde edilen sonuçlardaki varyasyonlar dikkat çekicidir (Atay ve ark., 2004; Onurlubaş, 2011). Onurlubaş (2011), çalışmasında tüketicilerin kırmızı et tüketiminde gelir seviyesinin pozitif yönde bir etkisi olduğunu bildirmiştir. Gelir düzeyinden bağımsız olarak kırmızı et tüketimine yönelik yürütülen bu araştırmada ise, gelir alt gruplarında bile kırmızı etin sevilerek tüketilebildiği görülmüştür. Mevcut çalışmada görülen bu davranış şekli, Karakuş ve ark. (2008)'nın yürüttükleri çalışmada da görülmüştür. 
Tablo 1.

Demografik ve Sosyo-Ekonomik Özellikler

\begin{tabular}{|c|c|c|c|}
\hline İncelen Faktörler & & $n$ & $\%$ \\
\hline \multirow[t]{2}{*}{ Cinsiyet } & Erkek & 70 & 70 \\
\hline & Kadın & 30 & 30 \\
\hline \multirow[t]{5}{*}{ Yaş } & $17 / 26$ & 4 & 4 \\
\hline & $27 / 36$ & 26 & 26 \\
\hline & $37 / 46$ & 50 & 50 \\
\hline & $47 / 56$ & 17 & 17 \\
\hline & $>57$ & 3 & 3 \\
\hline \multirow[t]{5}{*}{ Öğrenim Durumu } & ilkokul & 1 & 1 \\
\hline & Ortaokul & 0 & 0 \\
\hline & Lise & 8 & 8 \\
\hline & Ön Lisans & 17 & 17 \\
\hline & Üniversite & 74 & 74 \\
\hline \multirow[t]{5}{*}{ Hanedeki Kişi Sayısı } & 2 & 14 & 14 \\
\hline & 3 & 34 & 34 \\
\hline & 4 & 37 & 37 \\
\hline & 5 & 14 & 14 \\
\hline & $>6$ & 1 & 1 \\
\hline \multirow[t]{5}{*}{ Aylık Ortalama Hane Geliri } & $1500-2500$ & 2 & 2 \\
\hline & $2500-3500$ & 1 & 1 \\
\hline & $3500-4500$ & 8 & 8 \\
\hline & $4500-5500$ & 17 & 17 \\
\hline & $>5500$ & 72 & 72 \\
\hline
\end{tabular}

Antalya, Van ve Gaziantep'te yürütülen çalışmalarda kırmızı etin tüketiminde çoğunlukla koyun eti tercih edilmişken, Mersin'de yürütülen mevcut çalışmada ise Çine'de ve Elazığ'da yürütülen çalışmalara benzer olarak sığır eti tercih edilmiştir (Atay ve ark., 2004; Aygün ve ark., 2004; Karakuş ve ark., 2008; Tosun \& Hatırlı, 2009). Kırmızı etin satın alma şekli konusunda katılımcıların büyük çoğunluğunun eti kıyma ve kemiksiz parça şekli ile satın aldığı görülmüştür. Kırmızı etin tüketim şekli konusunda elde edilen sonuçlara göre Mersin ilinde, en çok mangalda (ızgara) et tüketildiği görülmüştür. Aynı şekilde, Karakuş ve ark. (2008), Gaziantep ilinde de kırmızı tüketiminin mangalda et şeklinde olduğunu bildirmiştir. Çine ve Van'da ise sebzeli yemek olarak tüketildiği görülmüştür (Atay ve ark., 2004; Aygün ve ark., 2004). Böyle bir sonuçtan, bölgesel ve dolayısıyla kültürel farklılıkların kırmızı et tüketimi-pişirimi şeklinin etkilediği söylenebilir.

Araştırma sonucunda elde edilen veriler cinsiyet, yaş, öğrenim durumu, hanedeki kişi sayısı ve aylık ortalama hane geliri dikkate alınmadan hayvan refahı açısından genel olarak incelendiğinde en fazla refah problemi yaşayan hayvan türü konusunda besi sığırını belirten katılımcılar, hayvan refahı konusunda en çok endişelendikleri durumun ise bakım ve besleme olduğunu bildirmişlerdir. Katılımcıların tarım personeli de olması göz önünde bulundurularak değerlendirildiğinde bakım-besleme-kesim-sağlık hizmetleri konusunda da benzer oranlarda görüş bildirmişlerdir. Ayrıca "ötenazi” cevabını verenlerin oranı (\%9) azımsanmayacak derecededir. Çiftlik hayvanlarının maruz kaldıkları refah problemleri üzerine sorulan sorularda, "yeterince bakım-beslemenin olmaması" ve "havalandırmanın yetersizliği" cevapları en yüksek oranda alınan cevaplardır. Bununla birlikte ahır-ağılların basık ve dar olması,
Tablo 2.

Tüketicilerin Kırmızı Et Tüketimine Yönelik Tutum ve Davranış Şekilleri

\begin{tabular}{|c|c|c|c|}
\hline & & $n$ & $\%$ \\
\hline \multirow[t]{5}{*}{ Öncelikli Et Türü } & Balık & 20 & 16 \\
\hline & Beyaz Et & 26 & 21 \\
\hline & Kırmızı Et & 60 & 48,3 \\
\hline & Av Etleri & 1 & 1 \\
\hline & Hepsi & 17 & 13,7 \\
\hline \multirow[t]{5}{*}{ Öncelikli Tercih Edilen Kırmızı Et } & Sığır & 51 & 44,3 \\
\hline & Koyun & 46 & 40,1 \\
\hline & Keçi & 16 & 13,9 \\
\hline & Deve & 0 & 0 \\
\hline & Diğer & 2 & 1,7 \\
\hline \multirow[t]{5}{*}{ Kırmızı Et Tüketim Şekli } & Haşlama & 29 & 18,8 \\
\hline & Firında & 41 & 26,6 \\
\hline & Mangalda & 49 & 31,9 \\
\hline & Yağda Kızartmalık & 18 & 11,6 \\
\hline & Diğer & 17 & 11,1 \\
\hline \multirow{4}{*}{$\begin{array}{l}\text { Sucuk, sosis ve salam gibi } \\
\text { işlenmiş kırmızı et ürünlerinin } \\
\text { tüketimi }\end{array}$} & Evet & 47 & 47 \\
\hline & Hayır & 12 & 12 \\
\hline & Ara Sira & 41 & 41 \\
\hline & Misafir Geldiğinde & 0 & 0 \\
\hline \multirow{5}{*}{$\begin{array}{l}\text { Kırmızı Et Tercih Etmeme } \\
\text { Nedenleri }\end{array}$} & Balık & 4 & 3,2 \\
\hline & Beyaz Et & 8 & 6,5 \\
\hline & Kokusu & 1 & 0,8 \\
\hline & Kolesterol & 32 & 25,8 \\
\hline & Pahalı & 79 & 63,7 \\
\hline \multirow{5}{*}{$\begin{array}{l}\text { Kırmızı Et Tercih Etme } \\
\text { Nedeniniz }\end{array}$} & Lezzetli & 48 & 36,3 \\
\hline & Besleyici & 53 & 40,1 \\
\hline & Alışkanlık & 18 & 13,6 \\
\hline & Ulaşımı Kolay & 3 & 2,4 \\
\hline & Diğer & 10 & 7,6 \\
\hline \multirow[t]{5}{*}{ Aylık Ortalaman Et Tüketimi } & Hiç & 1 & 1 \\
\hline & $1-2 \mathrm{~kg}$ & 32 & 32 \\
\hline & $3-4 \mathrm{~kg}$ & 45 & 45 \\
\hline & $5-6 \mathrm{~kg}$ & 15 & 15 \\
\hline & $>6$ & 7 & 7 \\
\hline \multirow{5}{*}{$\begin{array}{l}\text { Önceki Yıla Oranla Kırmızı Et } \\
\text { Tüketme Durumu }\end{array}$} & Çok Azaldı & 5 & 5 \\
\hline & Azaldı & 39 & 39 \\
\hline & Değişmedi & 53 & 53 \\
\hline & Az Arttı & 3 & 3 \\
\hline & Çok Arttı & 0 & 0 \\
\hline
\end{tabular}

hayvanlardan kapasitelerinden daha fazla verim beklenmesi ve hayvanların dolaşım alanlarının yetersizliği gibi alınan cevaplar da benzer oranlardadır. Şüphesiz katılımcıların hayvan refahı üzerine bu şekilde cevaplar vermesi mesleklerinden dolayı beklenen bir durumdur. Ancak, çiftlik hayvanlarının yaşamlarında öncelikli olarak düzeltilmesi gereken konular üzerindeki cevaplar incelendiğinde katılımcıların hayvanların acı ve yaralanma hususunda en düşük oranlarda cevaplar vermesi, çiftlik hayvanları üzerinde acı duygularının düşük olduğu kanısına varılmıştır. Kesim esnasında 
Tablo 3.

Tüketicilerin Kırmızı Et Satın Alımına Yönelik Tutum ve Davranış Şekilleri

\begin{tabular}{|c|c|c|c|}
\hline & & $n$ & $\%$ \\
\hline \multirow[t]{6}{*}{ Etin Satın Alındığı Yer } & Üreticiden Canlı Alırım & 8 & 6,2 \\
\hline & Belirli Bir Kasaptan & 67 & 51,9 \\
\hline & Et ve Balık Kurumu & 5 & 3,9 \\
\hline & Marketlerden & 41 & 31,8 \\
\hline & Rastgele Bir Kasaptan & 5 & 3,9 \\
\hline & Diğer & 3 & 2,3 \\
\hline \multirow{5}{*}{$\begin{array}{l}\text { Etin Satın Alınma Yerinin } \\
\text { Tercih Edilme Sebebi }\end{array}$} & Ucuz & 4 & 3,1 \\
\hline & Güvenilir & 91 & 71,1 \\
\hline & Sağlıklı & 29 & 22,6 \\
\hline & Çok Çeşit Et Bulunması & 2 & 1,6 \\
\hline & Diğer & 2 & 1,6 \\
\hline \multirow{5}{*}{$\begin{array}{l}\text { Kırmızı Et Satın Alırken } \\
\text { Dikkat Edilmesi Gerekenler }\end{array}$} & Tazelik & 83 & 65,3 \\
\hline & Ucuzluk & 11 & 8,7 \\
\hline & Yağsız Oluşu & 22 & 17,3 \\
\hline & Et Terbiyesi Yapılması & 4 & 3,1 \\
\hline & Diğer & 7 & 5,6 \\
\hline \multirow[t]{5}{*}{ Kırmızı Etin Satın Alma Şekli } & Kıyma & 68 & 40 \\
\hline & Kemiksiz & 60 & 35,3 \\
\hline & Kemikli & 31 & 18,2 \\
\hline & Porsiyonluk & 7 & 4,1 \\
\hline & Karkas & 4 & 2,4 \\
\hline \multirow[t]{5}{*}{ Porsiyonluk Eti Alma Şekli } & Bonfile & 8 & 6,8 \\
\hline & Pirzola & 12 & 10,1 \\
\hline & Biftek & 6 & 5,1 \\
\hline & Kuşbaşı & 88 & 74,6 \\
\hline & Diğer & 4 & 3,4 \\
\hline
\end{tabular}

dikkat edilmesi gereken konuların başında en çok hijyen durumuna öncelik veren katılımcılar, hayvanın strese girmemesi ve kesim yapacak kişinin tecrübeli olmasına da benzer oranlarda cevap vermişlerdir. Verilen bu cevaplardan, katılımcıların mesleki açıdan yeterliliklerinin ön plana çıktığı söylenebilir. Katıımcıların ürün etiketlerinde refah bilgisini istemesi ve hayvan refahına uygun şekilde yetiştirilmiş hayvanlardan elde edilmiş ürünler için ekstra para ödeme durumuna pozitifyaklaşmalarının yine mesleki deneyimlerden kaynaklandığı söylenebilir.

Man (2016), yaptığı çalışmasında çiftlik hayvanlarının yaşamlarındaki öncelikli olarak düzeltilmesi gereken refah durumuna yönelik sorusunda, katıımcıların "acı" cevabını verdikleri belirtmiştir. Araştırmacı çalışmasında, katııımıların ürün etiketinde refah bilgisi istemesine rağmen, hayvan refahına uygun koşullarda yetiştirilmiş hayvanlardan elde edilen ürünler için fazladan ücret ödemeyi red ettiklerini gözlemlemiştir. Halbuki, fazladan ücret ödeme istekliliği hayvan refahının iyileştirilmesi için başlangıç aşamalarından birisidir (Sert \& Uzmay, 2017). Optimal hayvan refahı seviyesine ulaşılması ancak bu şekilde mümkün olacaktır. Harvey ve Hubbard (2013)'a göre ise gıda ürünlerine yüksek ücret ödemeye gönüllü olan tüketici sayısı hayvan refahı uygulamalarının kamu veya üçüncü taraf denetimine tabi olduğu bilgisi ve aynı ürünü satın alan tüketici sayısının artışı ile paralel olarak artmaktadır. Oysa yapılan çalışmalarda, böyle
Tablo 4.

Tüketicilerin Hayvan Refahı Konusundaki Görüşleri

\begin{tabular}{|c|c|c|c|}
\hline Soru & Cevap & $N$ & $\%$ \\
\hline \multirow{4}{*}{$\begin{array}{l}\text { En Fazla Refah Problemi } \\
\text { Yaşayan Hayvan Grubu }\end{array}$} & Koyun & 16 & 4,2 \\
\hline & Keçi & 24 & 18,8 \\
\hline & Besi Sığırı & 50 & 39,4 \\
\hline & Süt Inekleri & 35 & 27,6 \\
\hline \multirow{6}{*}{$\begin{array}{l}\text { Çiftlik Hayvanlarında } \\
\text { Refahı Açısından Endişe } \\
\text { Duyulan Durum }\end{array}$} & Barınma & 26 & 13,8 \\
\hline & Bakım Ve Besleme & 68 & 36,2 \\
\hline & Nakliye & 24 & 12,8 \\
\hline & Kesim & 28 & 14,9 \\
\hline & Sağlık Hizmetleri & 25 & 13,3 \\
\hline & Ötanazi & 17 & 9 \\
\hline \multirow{8}{*}{$\begin{array}{l}\text { Çiftlik Hayvanlarının } \\
\text { Maruz Kaldıkları Refah } \\
\text { Problemleri }\end{array}$} & $\begin{array}{l}\text { Ahır-Ağılların Yeterince } \\
\text { Havalandırılmaması }\end{array}$ & 58 & 20,1 \\
\hline & $\begin{array}{l}\text { Ahır-Ağılların Basık ve Dar } \\
\text { Olması }\end{array}$ & 38 & 13,1 \\
\hline & $\begin{array}{l}\text { Bakıcıların Hayvanlara Kötü } \\
\text { Davranış Sergilemeleri }\end{array}$ & 12 & 4,2 \\
\hline & $\begin{array}{l}\text { Hayvanların Hareket ve olaşım } \\
\text { Alanlarının Yetersiz Olması }\end{array}$ & 49 & 17 \\
\hline & $\begin{array}{l}\text { Hayvanların Kendi Türlerine } \\
\text { Özgü Davranışları } \\
\text { Sergileyememesi }\end{array}$ & 17 & 5,9 \\
\hline & $\begin{array}{l}\text { Hayvanların Kapasitelerinden } \\
\text { Daha Fazla Verim Beklenmesi }\end{array}$ & 35 & 12,1 \\
\hline & $\begin{array}{l}\text { Veteriner Hekim Hizmetlerinin } \\
\text { Yetersiz Olması }\end{array}$ & 19 & 6,5 \\
\hline & $\begin{array}{l}\text { Hayvanların Yeterince Bakım ve } \\
\text { Beslemenin Yetersiz Yapılması }\end{array}$ & 61 & 21,1 \\
\hline \multirow{10}{*}{\begin{tabular}{|l|} 
Çiftlik Hayvanlarının \\
Yaşamlarında Öncelikli \\
Düzeltilmesi Gerekenler
\end{tabular}} & $\mathrm{ACl}$ & 14 & 4,9 \\
\hline & Açlık & 25 & 8,9 \\
\hline & Susuzluk & 15 & 5,3 \\
\hline & Hastalık & 38 & 13,5 \\
\hline & Yaralanma & 8 & 2,8 \\
\hline & Olumsuz Fiziki Şartlar & 66 & 23,4 \\
\hline & Korku ve Endişe & 17 & 6 \\
\hline & Isı Sorunları & 12 & 4,3 \\
\hline & $\begin{array}{l}\text { Normal Davranışları Ortaya } \\
\text { Koyamama }\end{array}$ & 23 & 8,2 \\
\hline & $\begin{array}{l}\text { Havalandırma ve Yetersiz Dar } \\
\text { Alan }\end{array}$ & 64 & 22,7 \\
\hline \multirow{4}{*}{$\begin{array}{l}\text { Çiftlik Hayvanlarının } \\
\text { Kesimi Esnasında } \\
\text { Dikkat Edilmesi } \\
\text { Gerekenler Durumlar }\end{array}$} & Hayvan Strese Sokulmamalıdır & 47 & 25,1 \\
\hline & $\begin{array}{l}\text { Kesim Yerinin Temizliği ve } \\
\text { Hijyen Koşulları }\end{array}$ & 77 & 41,1 \\
\hline & $\begin{array}{l}\text { Kesim Yapacak Kişinin Tecrübeli } \\
\text { Olması }\end{array}$ & 43 & 23,1 \\
\hline & $\begin{array}{l}\text { Kesim İşleminin Ağrısız Bir } \\
\text { Şekilde Yapılması }\end{array}$ & 20 & 10,7 \\
\hline \multirow{4}{*}{$\begin{array}{l}\text { Refah Bilgisi İster } \\
\text { misiniz? }\end{array}$} & Evet İsterim & 77 & 77 \\
\hline & Hayır İstemem & 6 & 6 \\
\hline & Hiç Düşünmedim & 13 & 13 \\
\hline & Fark Etmez & 4 & 4 \\
\hline \multirow{2}{*}{$\begin{array}{l}\text { Fazladan Ücret Öder } \\
\text { misiniz? }\end{array}$} & Evet & 52 & 52 \\
\hline & Hayır & 48 & 48 \\
\hline
\end{tabular}


bir sonucun üreticinin fazladan masraf yaparak hayvan refahına uygun yetiştiricilik yapılmasının teşvik edilmesini olumsuz etkilediği bildirilmiştir (Man, 2016). Mevcut çalışmada katılımcıların tarım personelinden oluşmasına rağmen elde edilen sonuçlardan, hayvan refahı kavramından hayvan sağlığının anlaşıldığı görülmüş ve dolayısıyla benzer bir durum ortaya çıkmıştır. Man (2016), hayvan refahı konusunda insanların bilinçlendirilmesi gerekliliğini savunması da, bu çalışmadan elde edilen sonuçları desteklemektedir.

\section{Sonuç ve Öneriler}

Mersin ilinde yürütülen bu çalışmada, tarım personellerinin tercih ettiği kırmızı et türü, sığır etidir. Kırmızı eti tercih etmelerinin asıl sebebinin besleyici olmasını belirten tarım personeli, kırmızı eti kendilerinin bildikleri ve güvendikleri bir kasaptan satın almayı tercih etmektedir. Etin pahalı olması, tarım personelinin et tüketimini olumsuz etkilemiştir. Sucuk, salam, sosis gibi işlenmiş et ürünleri tüketen tarım personeli, en çok mangalda pişirim şeklini tercih etmiştir. Tarım personelinin hayvan refahı anlayışından ise hayvan sağlığını ve dolaylı olarak tüketici sağlığının farkında oldukları kanısına varılmıştır. Günümüzde tüketicinin daha bilinçli hale gelmesi amacıyla kırmızı etin besin madde içeriği ve insan sağlığındaki önemi hakkında çeşitli bilgilendirmeler yapılmalı ve hayvan hakları bakımından tüketicilerin bilinç seviyesinin artırılmasına yönelik çalışmalara ağırlık verilmelidir.

Etik Komite Onayı: Çalışmanın yapılabilmesi için KSÜ Fen ve Mühendislik Bilimleri Etik Kurulu'ndan etik kurul izni alınmıştır.

Hakem Değerlendirmesi: Dış Bağımsız.

Yazar Katkıları: Fikir - A.K., A.T.T., O.A.; Tasarım - A.K., A.T.T., O.A.; Denetleme - A.K., A.T.T., O.A.; Kaynaklar - A.K., A.T.T., O.A.; Malzemeler - A.K., A.T.T., O.A.; Veri Toplanması ve/veya İşlemesi - A.K., A.T.T., O.A.; Analiz vel veya Yorum - A.K., A.T.T., O.A.; Literatür Taraması - A.K., A.T.T., O.A.; Yazıyı Yazan - A.K., A.T.T., O.A.; Eleştirel İnceleme - A.K., A.T.T., O.A.

Teşekkür: Bu çalışmanın planlanması ve anket sorularının hazırlanmasında desteklerini esirgemeyen Prof. Dr. Mürsel KÜÇÜK'e katkılarından dolayı teşekkür ederiz.

Çıkar Çatışması: Yazarlar çıkar çatışması bildirmemişlerdir.

Finansal Destek: Yazarlar bu çalışma icin finansal destek almadıklarını beyan etmişlerdir.

Ethics Committee Approval: Ethics committee permission was obtained from KSU Science and Engineering Sciences Ethics Committee in order to carry out the study.

Peer-review: Externally peer reviewed.

Author Contributions: Concept - A.K., A.T.T., O.A.; Design - A.K., A.T.T., O.A.; Supervision - A.K., A.T.T., O.A.; Resources - A.K., A.T.T., O.A.; Materials - A.K., A.T.T., O.A.; Data Collection and/or Processing - A.K., A.T.T., O.A.; Analysis and/or Interpretation - A.K., A.T.T., O.A.; Literature Search - A.K., A.T.T., O.A.; Writing Manuscript - A.K., A.T.T., O.A.; Critical Review - A.K., A.T.T., O.A.

Acknowledgments: We thank Professor Doctor Mürsel Küçük who provided full support in the preparation of survey questions and planning of this study for his contributions.

Conflict of Interest: The authors declared that they have no conflict of interest.

Financial Disclosure: The authors declared that this study has received no financial support.

\section{Kaynaklar}

Aktaş, G. (2020). Canlı hayvan ve karkas ithalatının kırmızı et fiyatlarına etkisi: Türkiye'de ithalatın regülasyonu. Gümrük ve Ticaret Dergisi, $7(21), 12-29$.

Anonymous. (2020). OECD. Meat consumption. Retrieved from https :/l data.oe cd.or g/agr outpu t/mea t-con sumpt ion.h tm (Accessed date 5 October 2021).

Anonymous (2021). OECD-FAO. Agricultural Outlook, 2017-2026.

Retrieved from https://stats.oecd.org/index.aspx?queryid=76854\# (Accessed date 5 October 2021).

Atay, O., Gökdal, Ö., Aygün, T., \& Ülker, H. (2004). Aydın ili Çine ilçesinde kırmızı et tüketim alışkanlıkları. 4. Ulusal Zootekni Bilim Kongresi, 1-4, 348-354.

Aygün, T., Karakuş, F., Yılmaz, A., \& Ülker, H. (2004). Van ili merkez ilçede kırmızı et tüketim alışkanlığı. 4. Ulusal Zootekni Bilim Kongresi, 1-4, 361-364.

Demirbaş, N., \& Saygın, Ö (2018). Türkiye'de kırmızı et tüketimi: Sorunlar ve öneriler. Selcuk Journal of Agricultural and Food Sciences, 32(3), 567-574.

Doğan, N. (2019). TRA1 bölgesinde (Erzurum, Erzincan, Bayburt) hanelerin kırmızı et, tavuk eti ve balık eti tüketimine yönelik mevcut durum üzerine bir araştırma. Türk Tarım ve Doğa Bilimleri Dergisi, 6(2), 285-295.

Ergönül, B. (2011). Meat consumption and buying behaviors of consumers living in Manisa city center, Turkey. Journal of Animal and Veterinary Advances, 10(3), 286-290.

Faul, F., Erdfelder, E., Lang, A. G., \& Buchner, A. (2007). G*Power 3: A flexible statistical power analysis program for the social, behavioral, and biomedical sciences. Behavior Research Methods, 39(2), 175-191.

Harvey, D., \& Hubbard, C. (2013). Reconsidering the political economy of farm animal welfare: An anatomy of market failure. Food Policy, 38, 105-114.

Karakaş, G. (2010). Tokat ili Kentsel Alanda Et ve Et Ürünleri Tüketiminde Tüketici Kararlarını Etkileyen Faktörlerin Belirlenmesi Üzerine Bir Araştırma. (s. 81). Yüksek Lisans Tezi). Gaziosmanpaşa Üniversitesi, Fen Bilimleri Enstitüsü, Tokat.

Karakuş, K., Aygün, T., \& Alarslan, E. (2008). Gaziantep ili merkez ilçede kırmızı et tüketim alışkanlıkları. Yüzüncü Yı Üniversitesi Tarım Bilimleri Dergisi, 18(2), 113-120.

Karlı, B., \& Bilgiç, A. (2007). Factors affecting meat and meat products consumption quantities in Sanliurfa Province. Akdeniz Üniversitesi Ziraat Fakültesi Dergisi, 2O(1), 127-136.

Lorcu, F., \& Bolat, B. A. (2012). Edirne ilinde kırmızı et tüketim tercihlerinin incelenmesi. Tekirdağ Ziraat Fakültesi Dergisi, 9(1), 71-85.

Man, H. Ö. (2016). Van'da Kırmızı Et Tüketim Alışkanlığı ve Tüketicilerin Hayvan Refahı Konusundaki Görüşleri. (s. 58). (Yüksek Lisans Tezi). Yüzüncü Yıl Üniversitesi. Sağlık Bilimleri Enstitüsü, Van.

Onurlubaş, E. (2011). Tüketicilerin Gıda Güvenliği Konusunda Bilinç Düzeylerinin Ölçülmesi: Tokat ili Örneği. (s. 180). (Doktora Tezi). Gaziosmanpaşa Üniversitesi, Fen Bilimleri Enstitüsü, Tokat.

Orak, S., Akgün, S., \& Orhan, H. (2006). Süleyman Demirel Üniversitesi öğrencilerinin beslenme alışkanlıklarının araştıııması. Süleyman Demirel Üniversitesi Tıp Fakültesi Dergisi, 13(2), 5-11.

Sarı̈̈zkan, S., Cevger, Y., Demir, P., \& Aral, Y. (2007). Erciyes Üniversitesi Veteriner Fakültesi öğrencilerinin hayvansal ürün tüketim yapısı ve alışkanlıkları. Erciyes Üniversitesi Sağılk Bilimleri Dergisi, 16(3), 171-179.

Saygi, H., \& Bayhan, B. (2011). Analysis of Turkey's import demand of fishery products. African Journal of Agricultural Research, 6(7), 1853-1856.

Sert, H., \& Uzmay, A. (2017). Adnan Menderes Üniversitesi Dünya'da hayvan refahı uygulamalarının ekonomik ve sürdürülebilirlik açısından değerlendirilmesi. Sosyal Bilimler Enstitüsü Dergisi, 4(4), 263-276.

Soro, N., \& Gültekin, U. (2020). Red meat consumption structure and consumer behavior in the urban area of Adana Province. Çukurova Tarım ve Gıda Bilimleri Dergisi, 35(2), 143-150. 
Taşkın, T., Engindeniz, S., Gbadamonsi, A. A., Kandemir, Ç., \& Koşum, N. (2020). Analysis of red meat consumption preferences of youth: A case study for Ege University students. Ege Üniversitesi Ziraat Fakültesi Dergisi, 57(1), 63-71.

Tosun, Ö. O., \& Hatırlı, S. A. (2009). Tüketicilerin kırmızı et satın alım yerleri tercihlerinin analizi: Antalya ili örneği. Suleyman Demirel University
Journal of Faculty of Economics, Administrative Sciences, 14(2), 433-445.

Yaylak, E., Taşkın, T., Koyubenbe, N., \& Konca, Y. (2010). İzmir illi Ödemiş ilçesinde kırmızı et tüketim davranışlarının belirlenmesi üzerine bir araştırma. Hayvansal Üretim, 51(1), 21-30. 